\title{
Research on the Effects of the Current Global Warming in the Context of Sustainable Development in Aghireșu Area, Cluj County
}

\author{
Marius SĂBĂDAŞ ${ }^{1 *}$, Marcel DÎRJA ${ }^{1}$, Mihai MAXIM² \\ ${ }^{1}$ Department of Land Measurements and Exact Sciences, University of Agricultural Sciences and \\ Veterinary Medicine, 3-5 Mănăstur St, 400372, Cluj-Napoca, Romania \\ ${ }^{2}$ Department of Soil and Technical Sciences, University of Agricultural Sciences and Veterinary \\ Medicine, 3-5 Mănăstur Street, 400372, Cluj-Napoca, Romania \\ *corresponding author: marius.sabadas@usamvcluj.ro
}

BulletinUASVM Horticulture 77(1) / 2020

Print ISSN 1843-5254, Electronic ISSN 1843-5394

DOI:10.15835/buasvmcn-hort: 2019.0026

\begin{abstract}
The objective of the research was to identify recent studies which have shown that previous climate changes are not comparable to the current global warming. The magnitude of these changes we all feel nowadays, and the effects most of the time with significant damage to both people and the environment, have reached a significant increase. It is well known that the rural environment is the area where food is produced, and that is why it is necessary not to postpone at all, the protective measures against the effects of global warming. Protecting air, water and soil resources against pollution and degradation must be the number one priority for sustainable rural development. The study area, namely Aghiresu area, is located in Cluj County, Transylvania, Romania, and it is known for its preponderant activity in agriculture and mining. It brings into attention, the situation of several limestone fields where the groundwater is strongly affected by the underground galleries. The principles of sustainable development especially of the rural environment, now more than ever, must take into account the quality of life, which depends on the protection of the environment and the existing resources.
\end{abstract}

Keywords: global warming, rural area, sustainable development

\section{Introduction}

Globally, various periods of warming and climate cooling have been recorded over time, but the way they have evolved with the industrial revolution of the last 100 years have led to radical negative changes in global warming. Today, when the geographical information systems allow experts for a good knowledge of the territory, and detailed land areas can be studied in detail, protection measures must be proposed, as soon as possible and long-term to eliminate the negative effects against sustainable development. During our research, in the studied area there were observed negative environmental effects due to lack of protection measures on the soil, lack of woodland and imperative necessity of land reclamation works.

Active engagement of as many people as possible should be considered by making them aware of the measures and conventions adopted 

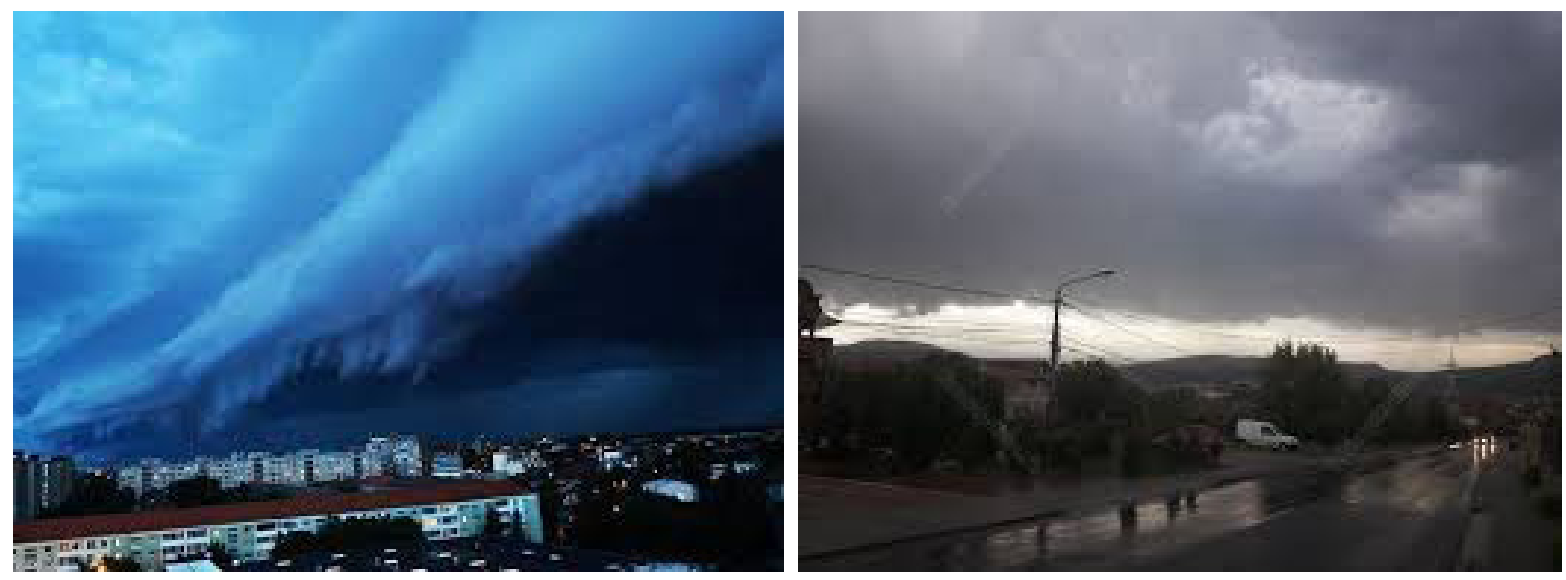

Figure 1. Thunderstorm which started from the west part of Romania in 2017

at international level to eliminate the negative effects of climate change, having beneficial consequences for the next generations. Awareness of the population about the unusual phenomena and the aggressive manifestations of nature, quite common in recent times is of great importance (Lindsay et al., 2009).

During the research works it was highlighted the need to implement, both locally and nationally, imperative measures for the protection of air, water and soil resources in viable projects for sustainable development (https://portal.afir. info). The present aim is to bring improvements in Romania and Cluj County and implicitly for Aghireşu area, regarding the prevention of phenomena caused by global warming.

\section{Materials and methods}

The area where the study was performed, Aghireșu area, with a surface of $6867 \mathrm{ha}$, is located in Cluj County, Transylvania, in the $\mathrm{N}-\mathrm{V}$ part of Romania (Fig. 1). Collecting field data, through the direct observation of degraded land and polluted waters photographing, measuring and statistical processing of data as well as studying official documents of the studied area available in the archives were the main activities of the research.

The research aims has been oriented to identify the climate change effects in Aghireșu area, in order to establish measures and works for protection and avoid natural disasters, taking into account that for protecting life must protect agricultural land, because there are significant economic agricultural exploitations. Considering the increase in the number of abnormal natural phenomena in the studied area, which affected the population and territory through short-term storms but with a very high wind speed, several preventive measures must be considered. Through such phenomena, significant material damage resulted in the deterioration of several house roofs, broken trees endangering the life of people on the streets as pedestrians or drivers unexpectedly.

\section{Results and discussions}

Between 1880-2012 the global average temperature increased by $0.85^{\circ} \mathrm{C}$, the last three decades being the warmest recorded in 800 years in the northern hemisphere (IPCC, 2014). In Europe, the average annual temperature during $2008-2017$ was $1.6-1.7^{\circ} \mathrm{C}$ higher than in the pre-industrial period (EEA, 2018). The agriculture, forestry, energy and tourism sectors are particularly affected because they are highly dependent on temperature and precipitation. The consequences of global warming are manifested in intensification of the hydrological cycle, which may increase the intensity and/or frequency of extreme phenomena such as droughts, cyclones and tropical storms and alteration of the precipitation regime on a regional and local scale.

In Cluj County, as well as in Aghireşu area, flood control is partially achieved through hydro-technical works such as embankments, regularizations, accumulations, and others. At the same time, the monitoring of the dangerous meteorological phenomena at the county level is carried out by measurements from the hydrometeorological network using lenses, rainfall meters, as well as global-radar systems. 


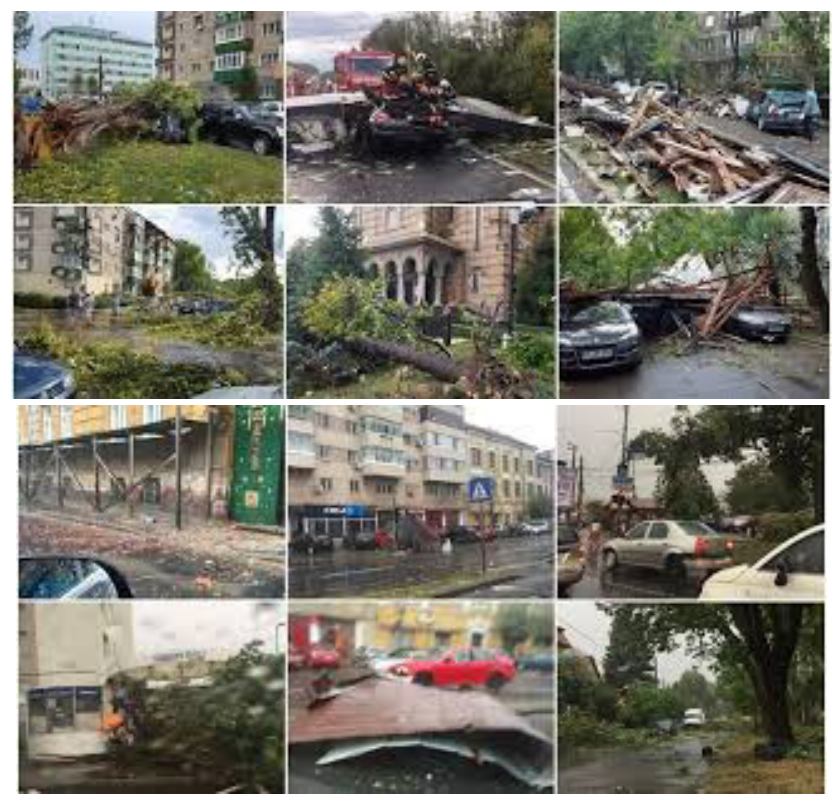

Figure 2. Damage produced in Banat area after strong thunderstorm
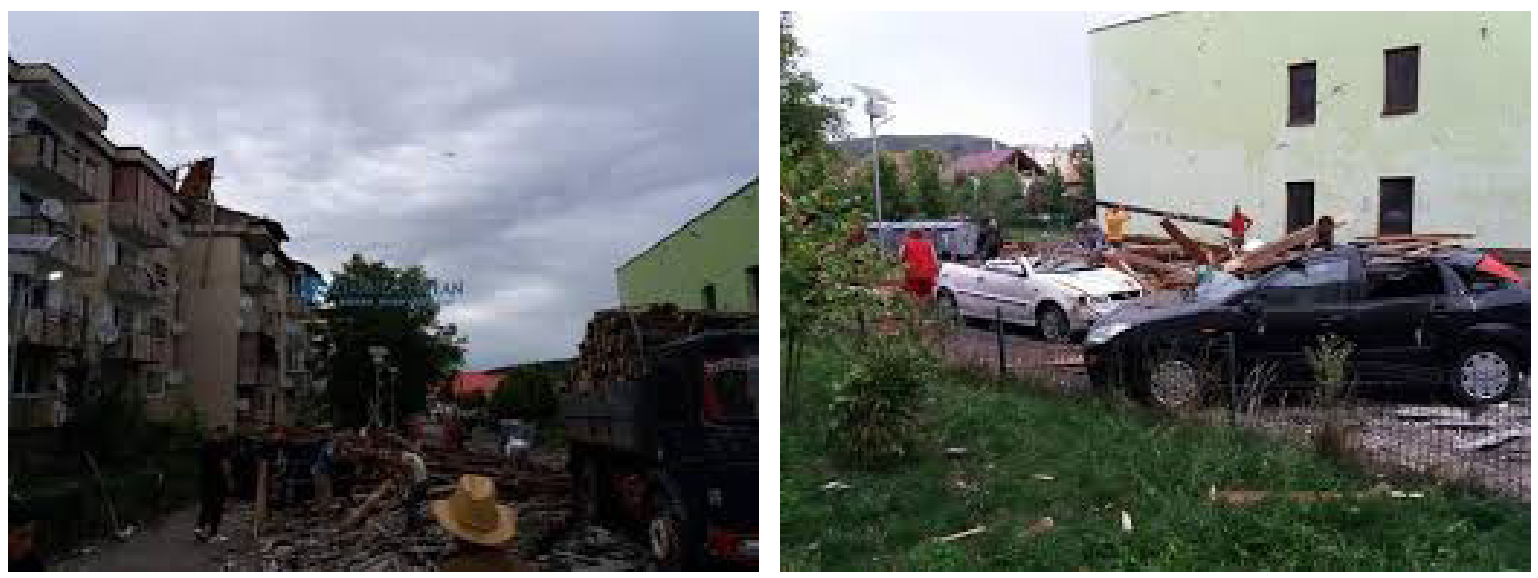

Figure 3. Damage produced in Aghireşu area after strong storm and wind

For example in 2017, following a thunderstorm with wind speeds that exceeded $100 \mathrm{~km} / \mathrm{h}$, which started from the west of Romania, from the Timisoara area (Fig. 2), and unfolded over several hundred km also affected Cluj County, and also Aghireşu area (Fig. 3).

Following the storm have resulted human victims, hundreds of hectares of destroyed forests, blocked roads, electricity networks and interrupted drinking water and many other material damages marked in the localities (Fig. 2 and 3).

Another example from Transylvania area, in 2018, after a period of two months of drought, hail and ice began to grow abnormally large and cause damage to agricultural and horticultural crops, orchards and stressed animals (Fig. 4). At the same time, material damage in localities was caused by the destruction of cars and house roofs.

Even in 2019, such phenomena have not been delayed to appear in the south of Romania, so that a repetition can be observed in the last three years of these unusual phenomena for our country against which prevention methods must be found. For the prevention of human victims, a good method that has already been put into practice by the emergency intervention services to alert the population regarding the phenomena of nature through alert messages transmitted directly on the mobile phone. 

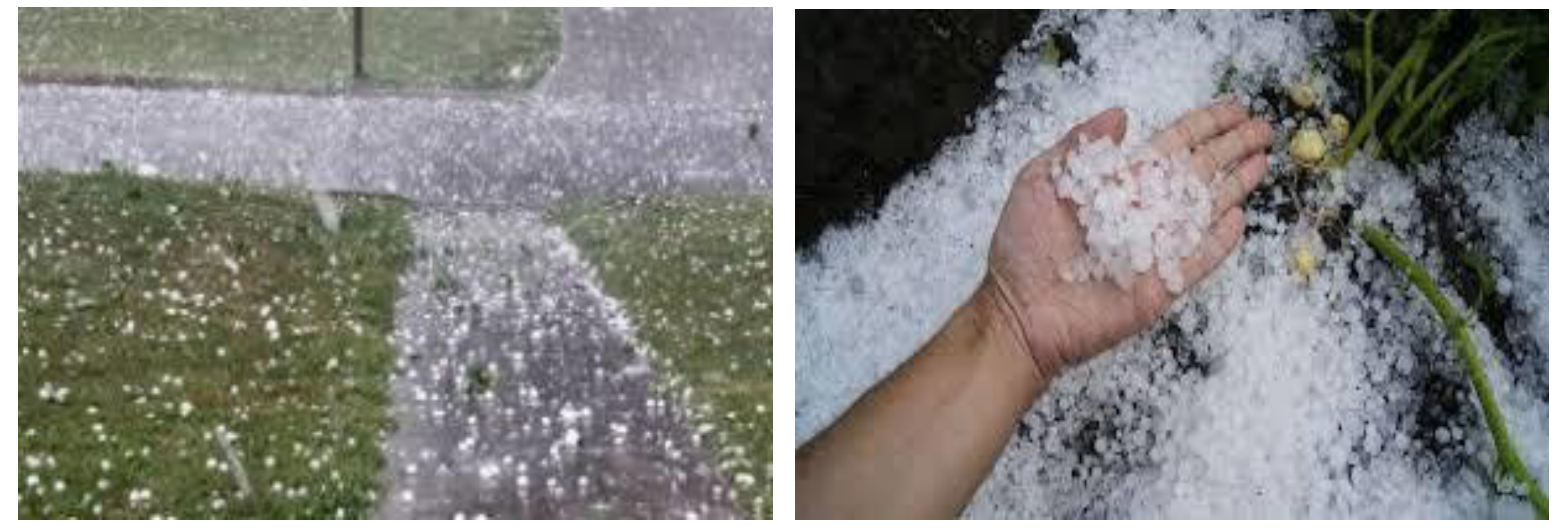

Figure 4. Hail and ice in large quantities in Salaj County

The modified rainfall regime can lead to flooding or reduced water resources, alter the flow of rivers, affect soil moisture and the life cycle of plants. Due to these anomalies, changes in the area distribution of some species of plants and animals are expected, and the life cycles of insects will be modified. At the economic level, the sectors that are most dependent on temperature and rainfall are agriculture, forestry, energy and tourism which are particularly affected (Dîrja and Budiu, 2006).

Based on the greenhouse gas emission scenarios, there are expected episodes with extreme rainfall and thunderstorms, exceeding 20 liters $/ \mathrm{m}^{2}$ in 24 hours, especially in hill and mountain areas and near the Black Sea coast, and an increase in the frequency and duration of heat waves (Bojariu et al., 2015).

Within the national territory, Transylvania is less exposed to the climatic risks than the Carpathian Mountains regions, due to its position within the Carpathian arch, but here, more frequent climatic hazards are expected. For the representative analysis of the climatic conditions, statistic data were collected from the Cluj-Napoca weather station, the nearest from Aghireşu area, (46 $46^{\prime} 59^{\prime \prime}$ north latitude, $23^{\circ} 34^{\prime} 00^{\prime \prime}$ east longitude, $410 \mathrm{~m}$ altitude). In Figure 5 are presented the medium temperatures registered during 1961 - 2014.

The analyzed data series show the presence of a heating phenomenon that has been accelerating since the last decade of the 20 th century, and during the period of 1961-2014, there is a tendency to increase the average annual temperatures, more pronounced after 1990, when almost all the values exceed the climatological average of 1961-1990.
The heating trend is also reflected in the increase in the average number of summer days with the maximum temperature exceeding $25^{\circ} \mathrm{C}$, from 51.8 days in 1961-1990 to 69.4 days in 19912015 . The changes in the average of the maximum number of consecutive summer days from 12.0 days in the period 1961-1990, up to 16.8 days in the period 1991-2015, suggest a higher frequency and intensity of the heat wave in the future.

In winter season, the heating is also felt by recording the decrease of the average number of winter days in which the maximum temperature was below $0^{\circ} \mathrm{C}$ from 35.1 days in 1961-1990 to 33.4 days in 1991-2015. For the period of 1961-2013, the analysis of the precipitation regime shows increases in the northwest of Romania where the studied area is located. For the autumn months, we can observe differences, with the tendency of increasing in the winter and spring months in the eastern part of the Apuseni Mountains (Bojariu et al., 2015).

The distributions of the annual precipitation, together with the significant increase of the temperatures in the warm season, suggest the increase of the frequency of drought phenomena during this century in the analyzed territory. The increase of the average amount of precipitation in the Someș river basin, together with the increase of the variability of precipitations and the number of days in which their quantity exceeds $20 \mathrm{liter} / \mathrm{m}^{2}$ suggests the increase of the risk of floods for the whole northwest region, including Aghireșu area (Bojariu et al., 2015).

Strategies for climate change slowdown include two directions: reducing greenhouse gas emissions and adapting to present and forecast 


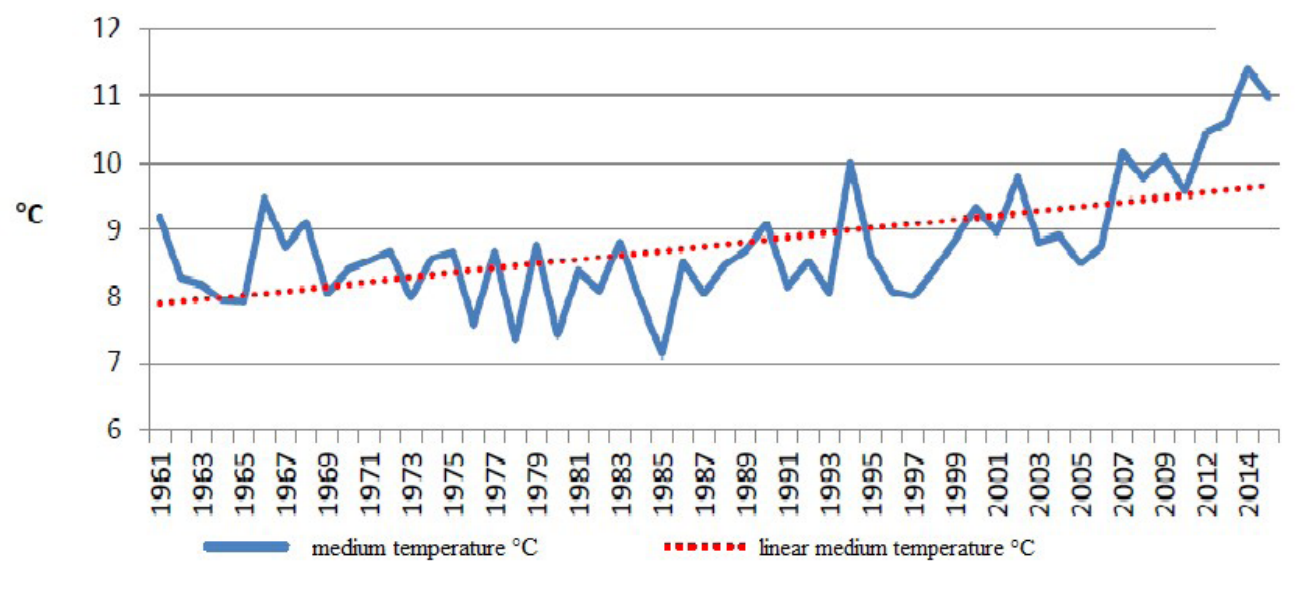

Figure 5. The evolution of the average annual temperature at the Cluj-Napoca weather station during 1961-2014 and the linear trend of growth

climate change. The issue of climate change began to be addressed in international policies through the Kyoto Protocol (1997), whereby the signatory states recognized the role of the anthropic factor in the emergence of global warming and assumed targets to reduce greenhouse gas emissions. The current aim is to apply the measures necessary to maintain global warming within the maximum limit of $2^{\circ} \mathrm{C}$ above the average temperature of the pre-industrial period, the target assumed at the December 2015, Paris Climate Conference (Delbeke and Vis, 2016).

Romania, as a member country of the European Union, has assumed EU strategies regarding reducing greenhouse gas emissions and mitigating the effects of climate change on the environment and society. At the national level, by 2020 , the objectives are: $20 \%$ reduction in the quantity of greenhouse gases emitted, increase to $20 \%$ of the total consumption of energy from renewable sources (Bojariu et. al, 2015).

Aghireșu area has a mixed profile of economic activity, namely agricultural and industrial, being an administrative unit in the rural area, in the territory of which the agricultural activities and a natural cover of the soil predominate, with a higher degree of artificialization only in the urban areas and the former industrial-mining areas. Through the predominant mining activities from the past, in the analyzed territory it was found the existence of land surfaces near the villages Arghişu, Dancu and Ticu, where due to the underground galleries, surface surges are observed, in these areas being completely prohibited constructions of houses and even agricultural activities (Cosoveanu, 2018).

The drastic reduction of the industrial activity after 1990 in Romania, as well as in the studied area, contributed to the decrease of the energy consumption and at the same time to the decrease of the emission of greenhouse gases. Adaptation to the effects of climate change must come from the local authorities, through measures applied to reduce greenhouse gas emissions and to adapt to climate change and population awareness actions on this phenomenon by disseminating adaptation measures at the community level. On the territory of Aghireşu there are areas of non-productive land, left unused due to the significant reduction of the industrial-mining area, areas that the local authorities can make available to those interested in such investments.

Energy consumption should be achieved by rehabilitation and modernization of the public lighting system pursuing greater efficiency (Constantin and Maracineanu, 2005); increasing the energy efficiency of buildings, by thermal insulation and the adoption of more efficient heating systems; promoting, among the population, the use of renewable energy sources through photovoltaic panels, solar panels for the production of domestic hot water, in this regard offering advice on the available financing sources.

According to the study, for the Aghireşu area, depending on the size of the built space and the available green space, the temperature differences may be a few degrees higher in the areas with 
dense constructions, the thermal discomfort being felt during the summer. Trees from localities and green areas such as gardens and parks offer a more oxygenated air and contribute to the reduction of air temperature near them and the emergence of a more favorable microclimate during periods of high temperatures (Cosoveanu , 2018).

The solutions that combine the living fence, the ornamental shrubs and trees lead to a significant improvement in the quality of the air, as well as a diminution of the effects of the heat wave and the flood control. One problem to consider is the waterproofing of the soil with tiles and asphalt which causes a faster surface runoff, with the risk of flooding during periods of prolonged rainfall or high torrential rainfall, or during periods of snow melting. In the case of an undersized and/ or unmanaged stormwater runoff and sewerage system, as is the case in certain sectors of the commune, there is a risk of flooding of streets and houses.

The climate changes predicted for the studied area make more likely the appearance of phenomena as heat, drought, torrential rains, hail, and high wind speeds. These phenomena can lead to deterioration of agricultural crops and the impossibility of protecting soil against erosion. The milder winter season, with reduced frost phenomena, can lead to a higher percentage survival of harmful insects for crop plants and massive attacks in the coming years. The change of seasons and the earlier beginning of spring, also means a faster start in the vegetation of plants, associated with possible risks related to late frosts and haze (Cosoveanu, 2018).

Forest activity is influenced by climate change and is expected to take place the drying processes of trees more frequently, especially those planted outside the optimal area of the species or at the limit of this area. In longer periods of drought it is expected to increase the frequency of forest fires. The forests and grasslands thathave been protected, greatly reduce surface runoff during rainfall and help reduce the risk of flooding. Another risk for the Aghireşu area, is that most of the electricity distribution and communications network is of aerial type, which can lead to interrupting the supply of electricity and communication services during storms and strong winds.

\section{Conclusion}

From the present research, it turns out that the analyzed territory is at risk especially from the perspective of flash floods, rapid floods due to short-term torrential rains, with large amounts of rainfall and landslides, favored by the clay component substrate. Due to long drought periods, and the presence of dry grass and forest vegetation, the risk of vegetation fires appears in the studied territory. The risks associated with climate change in the territory of Aghireșu area, require the preparation and information of the population so that they can be prepared through several measures of protection against extreme heat, floods, landslides, vegetation fires. Risk reduction for private and public buildings by the compulsory insurance policies against natural disasters could be of great importance.

In Aghireșu area, most of the land has agricultural use respectively $74 \%$ of the total area, it turned out that the application on these lands, of the good agro-environmental practices promoted by the Common Agricultural Policy, can contribute to the reduction of carbon emissions and to the protection of the environment on a very large area of the territory.

\section{References}

1. Bojariu R, Bîrsan MV, Cică R, Velea L, Burcea S, Dumitrescu A, Dascălu SI, Gothard M, Dobrinescu A, Cărbunaru F, Marin L (2015). Schimbările climatice - de la bazele fizice, la riscuri şi adaptare, Ed. Printech, Bucureşti

2. Constantin E, Maracineanu F (2005). Rolul imbunatatirilor funciare in dezvoltarea rurala durabila, Editura Cartea Universtara Bucuresti, (Capther 2).

3. Cosoveanu S (2018). Studiu privind impactul schimbărilor climatice şi adaptarea la acestea in comuna Aghireşu, judetul Cluj

4. Delbeke J, Vis P (Eds), (2016), EU Climate Policy Explained, online: https://ec.europa.eu/clima/sites/clima/ files/eu_climate_policy_explained_en.pdf - Accessed 10.06.19

5. Dîrja M, Budiu V (2006). Îmbunătăţiri funciare. Combaterea excesului de umiditate pe terenurile agricole, Ed. AcademicPres, Cluj-Napoca (Chapter 2).

6. European Environment Agency - EEA (2018). Global and European temperature, https://www.eea.europa. eu/data-and-maps/indicators/global-and-europeantemperature-8/assessment- Accessed 10.09.19

7. Intergovernmental Panel of Climate Change - IPCC (2014). Climate Change: Synthesis Report. Contribution of Working Groups I, II and III to the Fifth Assessment Report of the Intergovernmental Panel on Climate Change 
[Core Writing Team, R.K. Pachauri and L.A. Meyer (eds.)]. IPCC, Geneva, Switzerland, 151pp.

8. Lindsay C, Stringer S, Scrieciu S, Reed SM (2009). Biodiversity, land degradation, and climate change: Participatory planning in Romania.Doiorg/10.1016/j. apgeog.2008.07.008.

9. Ministerul Mediului, Strategia Naţională privind Schimbările Climatice (rezumat), http://mmediu.ro/ categorie/strategia-nationala-privind-schimbarile-climaticerezumat/171-Accessed 10.06.19

10. Rural_development/https://portal.afir.info/informatii_ generale_pndr_pndr_2007_2013_dezvoltare_rurala_ feadr/ Accessed 18.08.19
11. Rural_development/https://portal.afir.info/informatii_ generale_pndr_pndr_2007_2013_dezvoltare_rurala_ feadr/ Accessed 12.09.19

12. The World Bank România - WB (2015). Programul privind schimbările climatice şi o creștere economică verde, $\mathrm{cu}$ emisii reduse de carbon. Livrabilul A2.5. Strategia naţională privind schimbările climatice şi creşterea economică bazată pe emisii reduse de carbon. http:// www.fonduri-ue.ro/images/files/studii-Analize/48145/ Strategy\%20RO\%20FINAL\%20version.pdf--Accessed 10.06.19

13. http://www.meteoromania.ro/clima/adaptarea-laschimbarile-climatice/ Accessed 12.09.19 